\title{
Erratum to: The syntax of anaphoric possessives in Hungarian
}

\author{
Éva Dékány ${ }^{1}$
}

Published online: 10 January 2017

(C) Springer Science+Business Media Dordrecht 2017

\section{Erratum to: Nat Lang Linguist Theory (2015) 33: 1121-1168 DOI 10.1007/s11049-014-9278-0}

The article "The syntax of anaphoric possessives in Hungarian", written by Éva Dékány, was originally published Online First without open access. After publication in volume 33, issue 4, pages 1121-1168 the author decided to opt for Open Choice and to make the article an open access publication. Therefore, the copyright of the article has been changed to (C) The Author(s) 2015 and the article is forthwith distributed under the terms of the Creative Commons Attribution 4.0 International License (http://creativecommons.org/licenses/by/4.0/), which permits use, duplication, adaptation, distribution and reproduction in any medium or format, as long as you give appropriate credit to the original author(s) and the source, provide a link to the Creative Commons license, and indicate if changes were made.

The online version of the original article can be found under doi:10.1007/s11049-014-9278-0.

$$
\begin{aligned}
& \text { É. Dékány } \\
& \text { dekany.eva@nytud.mta.hu }
\end{aligned}
$$

1 Research Institute for Linguistics, Hungarian Academy of Sciences, Budapest, Hungary 